\title{
Victorian Literature and the Reception of Greece and Rome
}

'A louse on the locks of literature' was Tennyson's resentful characterisation of the critic John Churton Collins, who painstakingly enumerated the Laureate's allusions to classical texts. Tennyson felt he had been accused of unoriginality or even plagiarism, and was not appeased by the image of himself as a doctus poeta (learned poet) like Catullus, Virgil, or Horace. Collins (a former student of the distinguished classicist Benjamin Jowett) was attempting to establish English Literature as an academic discipline of equal seriousness with Classics by creating an alliance between the subjects. He favoured comparative studies of English writers and classical authors (read in translation, if students had no Latin or Greek), rather than a discipline based on philology. If he did not succeed in shaping the new discipline of English in the universities at the beginning of the twentieth century, his emphasis on 'intertextual studies' has much in common with recent scholarship on the Victorian reception of ancient Greece and Rome (Kearney 76).

The nineteenth century has come to be a privileged period within classical reception studies, with Romantic and Victorian Hellenism as prominent areas of interest. ${ }^{1}$ In the early 1980s, pioneering studies such as Richard Jenkyns' The Victorians and Ancient Greece and Frank M. Turner's The Greek Heritage in Victorian Britain reminded readers of the pervasive presence of the Greeks in the culture of the governing classes and the intellectual elite. ${ }^{2}$ Jenkyns and Turner explore the influence of ancient mythology, history and religion on 
Victorian literature, painting, sculpture, architecture, education, philosophy and politics, revealing the extent to which Greek examples were regarded as applicable to modern life. Greece provided familiar and idealised cultural touchstones for the classicallyeducated Victorian gentlemen who considered themselves heirs to the Hellenic tradition. Fifth-century Athens was an exemplary 'modern' civilisation for Matthew Arnold. Gladstone's reading of Homer (in his view, the closest available approximation of prelapsarian life) led him to the conclusion that modern evils such as prostitution, homosexuality, and divorce had no precedent in Greece (Bebbington).

'Writing about Greece was in part a way for the Victorians to write about themselves' comments Turner (Greek Heritage 8). That classical models should be chosen as a shared frame of reference is not surprising, since, Christopher Stray reminds us, for much of the nineteenth century classical education was taken for granted by men 'for whom it was simply the pervasive subject of formal learning' (Classics Transformed 46). Much that was written about the ancient world in the Victorian period offers more to the Victorianist than the modern classicist. Norman Vance observes that 'versions of civility and successful living, and metaphors and allusions to describe and reflect on contemporary life and thought' were derived from 'selective and often ahistorical and idealized readings' ("Victorian" 87). Such appropriations of the ancient world are notably partial and personal, and recent 
critics have shed light on the 'conflicting debates, idealisms and projections' within Victorian receptions of the classics (Goldhill 191).

In Who Needs Greek? (2002), Simon Goldhill describes 'an argument that brews throughout the [nineteenth] century about ... what the point of knowing Greek might be' (7). For many Victorian writers, whatever their own experience of education, Greek signifies 'intellectual ambition and the values that are attached to the intellectual lifestyle; it generates feelings of belonging to or exclusion from the educated elite' (Evangelista 2). As Stray notes in Classics Transformed, 'relatively fluid social boundaries' and a rapid increase in wealth derived from commerce and industry made education 'a crucial status marker, the battleground of class identification' (27; see also Bowen). The aspirational associations of studying Greek (and Latin) derived partly from a lack of utilitarian application, and a focus on developing a genteel literary style. Critics argued that mathematics, science and modern languages ought to form the core of a modern education.

Stray's study of classics in English schools and universities traces the development of the subject from 'amateurism to professionalism, from classical dominance to a pluralized field of specialisms' (12). Cambridge focused on philology until late in the century, when options such as archaeology, philosophy and ancient history were introduced (Stray Cambridge). At Oxford Greek literature, history and philosophy were read for content as well as linguistic training. Jowett, the translator of Plato's dialogues, was instrumental in establishing the new ethos of Oxford 
education, and 'insisted on the vivid contemporaneity and philosophical depth' of Greek texts (Dowling 64). Aristotle, whose Ethics had been at the core of Oxford classics, was partly displaced by Plato, since Jowett aspired to create ‘Platonic guardians for Britain and its empire' (Stray, Classics Transformed 122). ${ }^{3}$ He influenced Victorian literary culture through his students Pater, Swinburne and Symonds; Pater then taught Oscar Wilde and Gerard Manley Hopkins. The focus on Plato had consequences unforeseen by Jowett, as readings of the Symposium and the Phaedrus enabled the development of a radical counter-discourse of male love, a 'homosexual code' (Dowling xiii). Aesthetic writers such as Swinburne, Pater and Wilde reacted against earlier versions of Hellenism, such as Arnold's notion of the Greek spirit as a source of sweetness and light: 'Pater corrects Arnold's sanitised and bloodless idealisation of ancient Greece by focusing on the sidelined elements of primitivism, irrationality ... and the grotesque' (Evangelista 38).

The Cambridge classical scholar Jane Ellen Harrison is a focal point for discussions of Hellenism which emphasise the primitive and the irrational. In Yopie Prins' 'Greek Maenads and Victorian Spinsters', 'the entry of women into Greek studies, and especially their increased access to formal education' is examined through the examples of Harrison and Katherine Bradley (one half of the poetic duo Michael Field) (43). Prins reworks Dowling's ‘Hellenism and homosexuality in Victorian Oxford' as 'Hellenism and feminism in Victorian Cambridge' (46), and focuses on Pater as a mediating influence in the formation of new social identities, 
'new configurations of sexuality and gender' (47). Harrison's controversial theories about Greek art, religion and myth, based on developments in archaeology and anthropology, left behind the textual tradition of 'pure' scholarship for a combination of scientific knowledge and imaginative insight (Fiske 150-1). Her work on Greek religion, which focuses on chthonic cults rather than the worship of the Olympian gods, has been central to accounts of a 'dark side' of late Victorian Hellenism, associated with a more primitive Greece beneath the white marble surfaces admired by earlier generations (Evangelista; Olverson; Radford). Although Harrison is strongly associated with Cambridge, and particularly with Newnham, her experience of popular lecturing and her involvement in London literary society in the 1880s have recently attracted attention (Beard; Fiske). Reacting against 'the conservative and male-dominated academy,' Harrison connected the study of antiquity to 'intellectual freedom and innovation', contributing to a 'process of crosspollination' between Greek studies and aestheticism (Evangelista).

Like Plato, Sappho is central to aesthetic renegotiations of gender and sexuality and the construction of 'alternative literary sexual identities' (Maxwell 75). The mythic figure of Sappho as we currently understand her, Yopie Prins argues in Victorian Sappho, is a nineteenth-century construction. Prins examines versions of the Ovidian image of Sappho as a poetess who leaps from a cliff when deserted by her male lover, and as 'the very embodiment of lyric song ... an exemplary lyric figure' in Wharton's 1885 scholarly edition (61). Prins traces the emergence of 'a Sapphic 
strain in Victorian poetry' (19), in which poets such as Swinburne and Michael Field exploit the indeterminacy of Sappho's identity, and especially of her sexuality. Some of the texts discussed by Prins, Swinburne's poems 'Anactoria', 'Sapphics' and 'On the Cliffs' and Michael Field's volume Long Ago, have been further explored in a recent study of aestheticism and the fin de siècle by Stefano Evangelista, who suggests that Long Ago should be read as an 'imaginative biography of Sappho', like one of Pater's imaginary portraits or a dramatic monologue by Browning (102).

The remarkable variety of reworkings of classical myth in Victorian culture has inspired much recent scholarship. As Catherine Maxwell comments, 'mythic representations allow the expression of different kinds of human desire, whether this be sexual or amorous desire, the desire for certain kinds of identities or identifications, nostalgic desire for an imagined classical past, or a desire too transgressive even to be made manifest' (76). To take just one example, Persephone, snatched to the underworld by Hades, mourned by her mother the earth-goddess Demeter and finally allowed to return to the earth for only part of the year, was beginning to be understood as a myth about the cycle of the seasons. Ruskin, Swinburne, Pater, Tennyson, Hardy, Dante Gabriel Rossetti, Jean Ingelow and Dora Greenwell read and rewrite the myth in a variety of forms (Louis; Radford). In Tess of the D'Urbervilles, the characters unknowingly act out the myth of Persephone: corrupted by the modern world, they are incapable of 'reading mythically' and do not understand their roles (Bonaparte 416). Death, the bond between mother and 
daughter, fertility, and the figure of the fallen woman are aspects of the myth which appealed to its Victorian interpreters.

Notions of classical influence or the classical tradition suggest a handing down of material from past to present. Such conceptualisations of the relationship between past and present encouraged readers to believe that they could recover classical texts as they had been interpreted by their first audiences, stripping away intervening layers of interpretation. In this context, attempts by writers to translate or adapt ancient texts and tropes have been criticised for the intrusion of modern concerns or literary devices into ostensibly 'Greek' or 'Roman' works. Victorian poets, dramatists and novelists have been assessed for their imitative excellence and judged more or less as failures at a task that has much in common with the educational tradition of verse and prose composition. To take one example of such appraisals, Hugh Lloyd-Jones writes that Victorian poetry exhibits 'Greek decor' rather than 'real Greek influence', Arnold is only superficially Greek, and Swinburne ‘a very unhellenic author' (143). Redefining our relationship to the ancient world in terms of intertextuality and reception enables us to appreciate the Victorian qualities of Victorian interpretations of the classics, instead of dismissing them as 'unclassical' or 'unhellenic'. Reception allows for the active participation of readers and writers, placing the present and past in dialogue: 'when texts are read in new situations, they have new meanings' (Martindale "Reception" 298). 
Recent scholarship has emphasised the insightfulness of Virginia Woolf's essay 'On Not Knowing Greek', a remarkable critique of simplistic identification with an ancient and foreign culture. Woolf 'argues for a model of scholarship that takes into account cultural difference and a crucial margin of unknowability' (Evangelista 1-2).

For it is vain and foolish to talk of knowing Greek, ... since we do not know how the words sounded, or where precisely we ought to laugh, or how the actors acted, and between this foreign people and ourselves there is not only difference of race and tongue but a tremendous breach of tradition. All the more strange, then, is it that we should wish to know Greek, try to know Greek, feel for ever drawn back to Greek, and be for ever making up some notion of the meaning of Greek... (Woolf 93)

Woolf highlights the role of the imagination in any reconstruction of a past culture. For the writer rather than the scholar, 'Greece does not present itself as a language to be mastered, or a text to be edited, but as a supreme fiction, an ideal space that might yield a host of fine poetic imaginings' (Aske 35).

In a sonnet much discussed by critics, Keats famously encounters Homer not in Greek, but in Chapman's translation: a 'displacement which signifies, for the modern poet, the impossibility of a pure, unmediated return to origins.' (Aske 42; see also Goldhill). A childhood encounter with a major classical text in translation is a common event in the biographies of nineteenth-century writers. Pope's Homer encouraged an obsessive immersion in the Homeric stories, which was often later supplemented by a reading of the text in Greek. Browning's poem 'Development' 
(1889) traces an engagement with Homer from childhood games based on stories of the Trojan war, through Pope, to the Greek text and later through the question of Homer's identity. As Meilee Bridges comments, the poem exemplifies 'the dream of an intense, personal contact with the epic heroes of Homer's poetry'. By comparison with readers' imaginative conviction of the truth of the Homeric world, Bridges argues, attempts to prove the historicity of the epics by means of archaeology and philological research provoked 'disenchantment' (166). Cornelia Pearsall similarly argues that the 'debate over whether Troy was a mythic city or ... a historically verifiable one' was not as important to the poet as to the archaeologist: for Tennyson, Troy was an imaginative space created by Homer (122).

Creative interpretations of classical texts draw on previous receptions. Edith Hall's The Return of Ulysses (2008) surveys an astonishing range of responses to Homer in diverse art forms, in which the Victorian period is well represented in poetry, fiction, painting and the popular theatre. Intertextuality is a fundamental attribute of the epic tradition, which evolves by assimilating new texts and forms such as the Victorian dramatic monologue. 'Ulysses' is a poem spoken by Homer's Odysseus and Dante's Ulisse and Tennyson's Ulysses. The poet is like a Homeric bard, a role Odysseus himself takes on, crafting a new poem from well-known material. In Pearsall's reading, the character of Ulysses is part of a debate about politics and poetry between Gladstone and Tennyson, through the mediating figure of Arthur Hallam; Ulysses is a persuasive orator who is aware of his audience and 
hoping to enlist some of the Ithacans as mariners on a new voyage. Telemachus, she argues, is a different kind of hero, resembling Virgil's Aeneas rather than the Homer's Odysseus: 'prudent, decent, deserving, blameless, one skilled in civilizing others, subduing them to his mild yoke, a hero noted especially for his filial devotion, his tenderness and meet adoration for his household gods' (186). The resonances of such a description of masculinity for Britain's imperial ambitions are clear, yet it is not Telemachus who holds the reader's attention but Ulysses, with his appetite for exploration and experience undercut by melancholy awareness of the approaching end. Returning to the Odyssey and other Odyssean texts, we retain these impressions as part of our sense of the hero as he is constantly reread and reworked by poets and critics.

A. A. Markley argues in a study of Tennyson's classical reading and writing that Tennyson's ambitious 'reworkings of classical material contributed to a lifelong project of attempting to provide modern Britain with a new achievement in literature - a literature comparable to the great works of antiquity' (4). Traditional epic was 'a test that ... more major poets than not approached with fear and trembling' (Tucker 2). Rather than attempting a modern epic, poets chose to approach the epic tradition obliquely, producing 'epicizing poems of immense address' (Tucker 332), such as Clough's Bothie, Tennyson's The Princess and Idylls of the King, Matthew Arnold's 'Sohrab and Rustum' and 'Balder Dead', and Barrett Browning's Aurora Leigh (see also Jenkyns "Idea of Epic"). 
In accounts of the reception of the classics, literary studies intersect with cultural history, gender and sexuality, the history of education, art, sociology, translation studies, philology, anthropology, archaeology and history of science. The Roman poet Lucretius has recently attracted critics interested in conflicts between religion and science. Arnold, Tennyson, Hardy, Eliot and Barrett Browning were among those who saw in the poet a modern type of melancholy, enabling them to express uncertainty or conviction about the challenge to traditional religion following developments in scientific thought (Vance Victorians and Ancient Rome 83-4, 97-9). Mackenzie notes that Arnold intended to write a tragedy about Lucretius: thwarted by the publication of Tennyson's dramatic monologue, he reworked the Lucretian material into Empedocles on Etna (163; Markley 140-8). The reception of the scientific epic De Rerum Natura fits well with current interdisciplinary preoccupations: the poem 'figures prominently within debates on the relation between materialist science on the one hand and religion on the other' (Holmes 268). As an Epicurean philosopher, Lucretius was criticised as a decadent hedonist whose scientific naturalism anticipated Darwin's theories. Defenders of Epicurus, such as John Stuart Mill, or Pater in Marius the Epicurean, represented his ethics not as a defence of mindless sensual indulgence but as an ascetic philosophy 'interchangeable with more orthodox ethical positions' (Dawson 101-6, 112-3).

Essays on Victorian responses to Latin literature appear in diachronic studies such as the edited collections Roman Presences, Ovid Renewed and Horace Made New; reception has 
become a dominant concern in Cambridge Companions to classical authors, such as Stephen Harrison's survey of nineteenth- and twentieth-century receptions of Horace. Although Greek was a more reliable marker of social or intellectual superiority, phrases from Latin poetry were part of the currency of public life, recalled with comparative ease because authors such as Horace were drummed into schoolboys (Hurst 11-14). The Augustan poets offered 'access to the world of Greek letters and Greek civility by writing versions of Greek poetry in Latin' (Vance "Horace" 176). Their obviously allusive poetry might be read as an invitation to participate in creating new intertextual relationships. In naming his elegy for Baudelaire 'Ave atque Vale', after a line in Catullus's elegy for his brother, Swinburne places himself in the profoundly allusive genre of elegy (Sacks). With echoes of Catullus, Propertius and Tibullus, In Memoriam establishes Tennyson and Hallam in the roles of suffering poet and distant, sometimes cruel beloved (Markley 75-9). Thomas A. Hayward has shown that the Latin epigraphs in Clough's The Bothie of Tober-Na-Vuolich are not merely creating the atmosphere of a classical reading-party but outlining the narrative of the poem.

Apart from these studies of poetic influence, the Victorian reception of Rome has attracted less attention than Hellenism. 'Why the Greeks and not the Romans in Victorian Britain?' asked Turner in 1989, in line with a widespread perception that dominant Roman influences in the 'Augustan' eighteenth century give way to a nineteenth-century fascination with Greece. Jonathan Sachs argues against this 'zero-sum game where the 
more relevant Greece is seen to be for contemporary life, the less relevant Rome must be' (9). He examines the reception of Greece and Rome (and of the relationship between the two civilisations) in the Romantic period, particularly for political purposes: 'the deployment of classical examples in framing contemporary understandings of such central aspects of modernity as democracy, popular revolt, empire, and tyranny' (2). In the Victorian era, Rome might be associated with the French Revolution and later examples of republican nationalism, the successful administration of an empire by self-sacrificing and patriotic heroes, or the decadence which led to that empire's decline. These and other historical perspectives are represented in Vance's The Victorians and Ancient Rome (1997) and in accounts of Victorian classical painters (Landow; Liversidge and Edwards; Barrow).

As Rome became comparatively accessible to the tourist while Greece remained distant and fantastic, Latin was undeniably easier to access than Greek. The strangeness of the alphabet, indecipherable to an uninitiated reader, made Greek alluringly complex. Latin was associated rather with drudgery: the school curriculum was based on 'the rote learning of Latin grammar and syntax', followed by (for a more select group) an initiation into the 'cultural authority' of Hellenism (Stray Classics Transformed 21). For those who did not learn Latin, Roman history and mythology are widely reproduced in Victorian poetry, paintings, drama, school texts and children's books. Historical novelists employ Roman settings to dramatise the conversion of pagan characters to Christianity. The popularity of Bulwer-Lytton's novel The Last Days 
of Pompeii (1834) is reflected in the creation of a Pompeian Court at the Crystal Palace (Hales).

The lack of a formal classical education was not necessarily to be lamented. Victorian fiction vividly renders the incongruity of the rich classical inheritance and the dull educational model focused on the rote-learning of grammatical rules from textbooks such as the Eton Latin Grammar and the reduction of poetry to syntactical examples. Dickens and Eliot are fascinated by the process of classical education, yet openly sceptical about its effectiveness for uncomprehending Paul Dombeys and Tom Tullivers. The biographies of Victorian writers demonstrate that those who did not study the classical languages at school and university could (laboriously but perhaps in the end no less successfully) learn from textbooks, study by correspondence or get help from a mentor. Such methods of classical education were particularly used by women before solitary learning in the home was replaced by formal education in girls' schools and women's colleges in the second half of the nineteenth century, but they also account for at least part of the classical learning of Robert Browning, Thomas Hardy and Anthony Trollope.

However extensively they read classical texts, those who learned Latin or Greek at home remained aware that they lacked the intensive training of their universityeducated contemporaries. The autodidact who acquires sufficient learning to be worthy of admission to the ancient universities, proving that he or she could rival men with a classical education, is a nineteenth-century fantasy figure notably 
embodied in Hardy's Jude the Obscure. Although Hardy's hero is a man, his failure to achieve the required level of scholarship and the harsh admonitions he receives for his ambition represent fears shared by middle-class women and working men as outsiders seeking to enter the privileged world of the university. Autodidacts considered it worthwhile to read 'great books', including classical texts, because they 'offered artistic excellence, psychological insights, and penetrating philosophy to the governing classes' and therefore 'the politics of equality must begin by redistributing this knowledge to the governed classes' (Rose 7). For such readers, a hard-won understanding the content of classical texts took precedence over the philological concerns of scholars. Like Dorothea Brooke in George Eliot's Middlemarch, they were attracted by the reputation of ancient authors as sources of wisdom and truth, even if the men who were already able to read the texts did not seem to embody those values.

Translations were an important means of access to the content of ancient literature. In the Victorian period 'the background of those producing translations became much wider, and there were more opportunities for those outside the traditional aristocratic or scholarly fields to publish their work' (Hardwick Translating Words 25). With the notable exceptions of Jowett (Plato) and Jebb (Sophocles), professional classicists 'regarded their chief task as the establishment of authentic Greek and Latin texts', so that 'the endeavour of interpretation and commentary' was largely left to amateur scholars including Gladstone, Matthew Arnold and Samuel Butler (Turner Contesting Cultural Authority 286-7; Dougher). 
Authors who produced translations or adaptations of classical texts include Elizabeth Barrett and Robert Browning, Tennyson, Swinburne, Edward FitzGerald and Augusta Webster. A competitive culture of translation is exemplified in a private debate between Gladstone and Tennyson over the way to translate Homer (Joseph), as well as in Arnold's more public and acrimonious pronouncements in 'On Translating Homer' (1860-1). Review articles in periodicals such as Blackwood's Edinburgh Magazine sometimes compared multiple versions of the same passage, giving the non-classical reader some sense of what was at stake in the translation of a particular text. Such articles were a valuable resource for the non-classical reader. Shanyn Fiske demonstrates that Blackwood's articles on Homer (by Thomas De Quincey and John Wilson) shaped Charlotte Brontë's thinking about 'the nature of literary composition' and her treatment of home and homesickness in Villette (74, 97-111).

Robert Browning's translations and adaptations of Greek tragedy, particularly his Agamemnon, have recently attracted attention for their idiosyncratic use of language. If English poetic diction aspired to emulate Greek in the use of features such as compound epithets (Haynes), Browning took the attempt to reproduce in English the effect of reading Greek still further. His translation 'seems to reverse source language and target language' and 'undoes the opposition between the two languages altogether, as it moves into an interlingual realm' (Prins “Violence Bridling Speech" 151-2; see also Matthew Reynolds; Turtle). Kathleen Riley's discussion of Browning's poem Aristophanes' Apology (1875) relates the embedded 
translation of Euripides' Herakles to Elizabeth Barrett's admiration of the tragedian's humanity. Riley explores Victorian readers' mixed responses to Aristophanes' Apology and concludes her account of the poem with a reading which emphasises the effectiveness of Browning's versification 'in its re-creation of the original dramatic impact', capturing 'the suspense and nervous movement of the original passage' (199).

Translations of Greek texts by women have been the focus of much recent study. Elizabeth Barrett (Browning) wrote two versions of Prometheus Bound: the first fairly literal and the second, written after much discussion with Robert Browning, 'permeated with Christian notions of sin, atonement, martyrdom and selflessness' (Wallace 332; see also Falk "EBB and her Prometheuses"; Prins "Différance of Translation"; Drummond). She also translated 'sentimental and erotic verses' for a friend's projected 'Classical Album', including the parting of Hector and Andromache from Homer's Iliad and one of Theocritus' Idyls (Wallace 333-6). Augusta Webster's close, line-by-line translations of Prometheus Bound (1866) and Medea (1868) impressed contemporary critics with their fidelity to the Greek plays. Webster articulated her ideas about translation in a review of Browning's version of Agamemnon: although she admired his dogged fidelity to the text, she felt that the obscurity of his language exceeded even that of Aeschylus.

The place of women (particularly of women writers) in Victorian Hellenism is a rapidly developing area of interest. In the work of Jenkyns and Turner, the notable 
Hellenists Elizabeth Barrett Browning, George Eliot and Jane Ellen Harrison were granted an exceptional status as female classicists in the nineteenth century. Rowena Fowler's account of the richness of women's literary responses to ancient Greece ('On Not Knowing Greek'), placed these writers in a literary tradition in which women writers identify with their female predecessors and peers in drawing on the classics. As well as exploring the obstacles to scholarship faced by women, Fowler notes their satirical resistance to the kind of pompous male classicist deftly skewered by Woolf in Jacob's Room (337) and the representation of the classics by Charlotte Brontë as 'weapons with which men torment and oppress women' (345). Recent studies have continued to examine Barrett Browning, Eliot and Harrison as preeminent in the Victorian reception of Greek culture, and have also shown that their outstanding attainments in classical studies inspired other women - particularly women with literary ambitions - to study Latin and Greek (Hurst). The increasing number of women writers reassessed in the light of their readings of classical texts and myths includes Emily Pfeiffer, Florence Nightingale, A. Mary F. Robinson, Vernon Lee and Michael Field (Olverson; Monros-Gaspar; Prins “Ladies' Greek”; Evangelista; Thain). Nevertheless, the lack of a formal classical education left even the most accomplished female classicists with anxieties about the 'inadequacy and amateurism' of their scholarship, a vulnerability recognised by Barrett Browning in the much-quoted phrase from Aurora Leigh, 'lady's Greek' (Fiske 7). 
The tragedies Augusta Webster chose to translate - Prometheus Bound and Medea - dramatise the social problems which dominated her own era: 'issues of obligation, community, freedom, tyranny and oppression of woman' (Hardwick "Women, Translation and Empowerment" 183). She responded creatively to classical texts: having translated Medea, with a particular forcefulness in the speech in which the heroine laments the wrongs of women, Webster went on to explore Medea's grievances against Jason in the dramatic monologue 'Medea in Athens'. Webster and Amy Levy emphasise Jason's cruel desertion and Medea's fear of losing her children, and draw attention to the persistence of sexual double standards (Sutphin; Hurst; Fiske). In Adam Bede, Daniel Deronda and Felix Holt, George Eliot suggests parallels between Medea and her characters, offering complex and not entirely unsympathetic renderings of the tragic heroine, as part of her larger project of reworking Greek myth in the modern form of the novel (King; Jenkyns, Victorians; Easterling; Travis). On the stage, Medea (in burlesques and tragedies) put the case for an extension of women's legal rights relating to divorce and infant custody when popular entertainments based on the myth highlighted married women's lack of autonomy. Medea and Clytemnestra catered to the public fascination with female murderers which was to emerge in sensation novels such as Lady Audley's Secret (Hall and Macintosh 391-429; see also Fiske 24-63).

Our understanding of Victorian Hellenism is incomplete if it is limited to such noted cultural events as the Antigone set to music by Mendelssohn which inspired George 
Eliot's essay ‘The Antigone and its Moral' (Hall and Macintosh 317-332) or the 1880 performance of Agamemnon at Oxford, which reflected a contemporary fascination with Schliemann's archaeological discoveries and Robert Browning's recent translation of the play (451-6). Recent research by Edith Hall and Fiona Macintosh into the performance of ancient drama in the Victorian theatre has brought to light a much more complex and lively popular culture which draws on classical drama. Burlesques appealed to 'working- and lowermiddle-class people, of both sexes' and satisfied Dickens's 'conventional mid-nineteenthcentury taste for farce, sentimentality and melodrama' (350-3). Tragedy, comedy and epic all received the burlesque treatment, being rewritten in absurd rhyming verse, with versions of popular song, dances, lavish spectacle and transvestism (358-71). Such theatrical extravaganzas reached audiences largely composed of people who would never read Homer or Euripides in the original language or even stumble through the Eton Latin Grammar. The study of the Victorian reception of the classics has been greatly enriched by investigations of the fascinating variety of sources of classical culture available to those who could not read the ancient languages, and much remains to be discovered. 
Endnotes

1. Earlier books on classical influences or the classical tradition in English literature which cover the Victorian period include Bush; Highet; Thomson; M. L. Clarke; Ogilvie. Studies of Victorian authors include Matthew Arnold (Anderson, DeLaura); George Eliot (Rendall; Wiesenfarth); Tennyson (Pattison; Redpath).

2. For the reception of Greece and Rome in nineteenth-century America, see Winterer, Culture of Classicism and Mirror of Antiquity.

3. For the Greek and Latin requirements for entering the Indian Civil Service, see Vasunia. 
Works Cited

Anderson, Warren D. Matthew Arnold and the Classical Tradition. Ann Arbor: U of Michigan P, 1965.

Aske, Martin. Keats and Hellenism: An Essay. Cambridge: CUP, 1985.

Barrow, Rosemary. The Use of Classical Art and Literature by Victorian Painters, 1860-

1912: Creating Continuity with the Traditions of High Art. Lewiston, NY; Lampeter:

Edwin Mellen Press, 2007.

Beard, Mary. The Invention of Jane Harrison. Cambridge, MA; London: Harvard UP, 2000.

Bebbington, David. "Gladstone and the Classics." A Companion to Classical Receptions. Eds. Lorna Hardwick and Christopher Stray. Oxford: Blackwell, 2008. 86-97. Bonaparte, Felicia. "The Deadly Misreading of Mythic Texts: Thomas Hardy's Tess of the D'Urbervilles." International Journal of the Classical Tradition 5 (1999): 415-31.

Bowen, James. "Education, Ideology and the Ruling Class: Hellenism and English Public Schools in the Nineteenth Century." Rediscovering Hellenism: The Hellenic Inheritance and the English Imagination. Ed. G. W. Clarke. Cambridge: CUP, 1989. 16186.

Breay, Claire. "Women and the Classical Tripos 1869-1914." Classics in 19th-and 20thCentury Cambridge: Curriculum, Culture and Community. Ed. Christopher Stray. Cambridge: Cambridge Philological Society, 1999. 48-70. 
Bridges, Meilee. "The Eros of Homeros: The Pleasures of Greek Epic in Victorian Literature and Archaeology." Victorian Review 34 (2008): 165-83.

Brown, Sarah Annes. "Embedded Ovidianism: Beddoes' 'Pygmalion' and Browning's the Ring and the Book." The Metamorphosis of Ovid: From Chaucer to Ted Hughes.

London: Duckworth, 1999. 155-80.

Bush, Douglas. Mythology and the Romantic Tradition in English Poetry. Cambridge, MA: Harvard UP, 1937.

Clarke, G.W., ed. Rediscovering Hellenism: The Hellenic Inheritance and the English Imagination. Cambridge: CUP, 1989.

Clarke, M. L. Classical Education in Britain, 1500-1900. Cambridge: CUP, 1959.

Dawson, Gowan. Darwin, Literature and Victorian Respectability. Cambridge: CUP, 2007.

DeLaura, David. Hebrew and Hellene in Victorian England. Austin: U of Texas P, 1969.

Dentith, Simon. Epic and Empire in Nineteenth-Century Britain. Cambridge: CUP, 2006.

Dougher, Sarah. "An Epic for the Ladies: Contextualizing Samuel Butler's Theory of Odyssey Authorship." Arethusa 34 (2001): 173-84.

Dowgun, Richard. "Some Victorian Perceptions of Greek Tragedy." Browning Institute Studies 10 (1982): 71-90.

Dowling, Linda C. Hellenism and Homosexuality in Victorian Oxford. London: Cornell UP, 1994. 
Drummond, Clara. "A 'Grand Possible': Elizabeth Barrett Browning's Translations of Prometheus Bound." International Journal of the Classical Tradition 12 (2006): 507-62. Easterling, P.E. "George Eliot and Greek Tragedy." George Eliot Review 25 (1994): 5667.

Edwards, Catharine, ed. Roman Presences: Receptions of Rome in European Culture, 1789-1945. Cambridge: CUP, 1999.

Evangelista, Stefano. British Aestheticism and Ancient Greece: Hellenism, Reception, Gods in Exile. Basingstoke: Palgrave Macmillan, 2009.

Falk, Alice. "Elizabeth Barrett Browning and Her Prometheuses: Self-Will and a Woman Poet." Tulsa Studies in Women's Literature 7 (1988): 69-85.

---. "Lady's Greek without the Accents: Aurora Leigh and Authority." Studies in Browning and His Circle 19 (1991): 84-92.

Fiske, Shanyn. Heretical Hellenism: Women Writers, Ancient Greece, and the Victorian Popular Imagination. Athens, OH; London: Ohio UP, 2008.

Fowler, Rowena. "''On Not Knowing Greek": The Classics and the Woman of Letters." Classical Journal 78 (1983): 337-49.

---. "Moments and Metamorphoses: Virginia Woolf's Greece", Comparative Literature, 51 (1999), 217-42.

France, Peter, and Kenneth Haynes, eds. The Oxford History of Literary Translation in English, Vol. 4: 1790-1900. Oxford: OUP, 2005. 
Gillespie, Stuart, ed. The Poets on the Classics: An Anthology of English Poets' Writings on the Classical Poets and Dramatists from Chaucer to the Present. London: Routledge, 1988.

Goldhill, Simon. Who Needs Greek? Contests in the Cultural History of Hellenism.

Cambridge: CUP, 2002.

Hales, Shelley. "Re-Casting Antiquity in the Crystal Palace." Arion 14 (2006): 99-133.

Hall, Edith. The Return of Ulysses: A Cultural History of Homer's Odyssey. London: I. B.

Tauris, 2008.

Hall, Edith, and Fiona Macintosh. Greek Tragedy and the British Theatre, 1660-1914.

Oxford: OUP, 2005.

Hall, Edith, Fiona Macintosh, and Oliver Taplin, eds. Medea in Performance 1500-2000.

Oxford: Legenda, 2000.

Hardwick, Lorna. Translating Words, Translating Cultures. London: Duckworth, 2000.

---. "Women, Translation and Empowerment." Women, Scholarship and Criticism:

Gender and Knowledge C. 1790-1900. Eds. Joan Bellamy, Anne Laurence and Gillian Perry. Manchester: Manchester UP, 2000. 180-203.

Hardwick, Lorna, and Christopher Stray, eds. A Companion to Classical Receptions.

Oxford: Blackwell, 2008.

Harrison, Stephen. "The Reception of Horace in the Nineteenth and Twentieth

Centuries." The Cambridge Companion to Horace. Ed. Stephen Harrison. Cambridge:

CUP, 2007. 334-46. 
Haynes, Kenneth. English Literature and Ancient Languages. Oxford: OUP, 2003.

Hayward, Thomas A. "The Latin Epigraphs in 'the Bothie of Tober-Na-Vuolich'."

Victorian Poetry 21 (1983): 145-55.

Highet, Gilbert. The Classical Tradition: Greek and Roman Influences on Western

Literature. London: OUP, 1949.

Hingley, Richard. Roman Officers and English Gentlemen: The Imperial Origins of Roman Archaeology. New York: Routledge, 2000.

Holmes, John. "Lucretius at the Fin De Siècle: Science, Religion and Poetry." English Literature in Transition, 1880-1920 51 (2008): 266-80.

Hurst, Isobel. Victorian Women Writers and the Classics: The Feminine of Homer. Oxford: OUP, 2006.

Jenkyns, Richard. "The Idea of Epic in the Nineteenth Century." Epic Interactions: Perspectives on Homer, Virgil, and the Epic Tradition. Eds. M. J. Clarke, B. G. F. Currie and R. O. A. M. Lyne, 2006. 131-57.

---. The Victorians and Ancient Greece. Oxford: Blackwell, 1980.

Joseph, Gerhard. "The Homeric Competitions of Tennyson and Gladstone." Browning Institute Studies 10 (1982): 105-15.

Kallendorf, Craig, ed. A Companion to the Classical Tradition. Oxford: Blackwell, 2007. Kearney, Anthony. "Making Tennyson a Classic: Churton Collins' 'Illustrations of Tennyson' in Context." Victorian Poetry 30 (1992): 75-82. 
King, Jeannette. Tragedy in the Victorian Novel: Theory and Practice in the Novels of George Eliot, Thomas Hardy and Henry James. Cambridge: CUP, 1978.

Landow, George P. "Victorianized Romans: Images of Rome in Victorian Painting." Browning Institute Studies 12 (1984): 29-51.

Liversidge, M. J. H., and Catharine Edwards. Imagining Rome: British Artists and Rome in the Nineteenth Century. London: Merrell Holberton, 1996.

Lloyd-Jones, Hugh. "Feet on the Mantelpiece." Greek in a Cold Climate. London: Duckworth, 1991. 138-43.

Louis, Margot K. Persephone Rises, 1860-1927: Mythography, Gender, and the Creation of a New Spirituality. Aldershot: Ashgate, 2009.

Mackenzie, Donald. "Two Versions of Lucretius: Arnold and Housman." Translation and Literature 16 (2007): 160-77.

Markley, A. A. Stateliest Measures: Tennyson and the Literature of Greece and Rome. Toronto, ON: U of Toronto P, 2004.

Marshall, Gail. Actresses on the Victorian Stage: Feminine Performance and the Galatea Myth. Cambridge: CUP, 1998.

Martindale, Charles, ed. Ovid Renewed: Ovidian Influences on Literature and Art from the Middle Ages to the Twentieth Century. Cambridge: CUP, 1988.

---. "Reception." A Companion to the Classical Tradition. Ed. Craig Kallendorf. Oxford: Blackwell, 2007. 297-311. 
Martindale, Charles, and David Hopkins, eds. Horace Made New: Horatian Influences on British Writing from the Renaissance to the Twentieth Century. Cambridge: CUP, 1993.

Maxwell, Catherine. "Victorian Literature and Classical Myth: Introduction." Victorian Review 34 (2008): 75-82.

Monros-Gaspar, Laura. "The Voice of Cassandra: Florence Nightingale's Cassandra (1852) and the Victorian Woman." New Voices in Classical Reception Studies 3 (2008). <http://www2.open.ac.uk/ClassicalStudies/GreekPlays/newvoices/issue\%203/Monro sGaspar.pdf>.

Ogilvie, R. M. Latin and Greek: A History of the Influence of the Classics on English Life from 1600 to 1918. London: Routledge \& Kegan Paul, 1964.

Olverson, T. D. Women Writers and the Dark Side of Late Victorian Hellenism.

Basingstoke: Palgrave Macmillan, forthcoming 2009.

Pattison, Robert. Tennyson and Tradition. Cambridge, MA; London: Harvard UP, 1979.

Pearsall, Cornelia D. J. Tennyson's Rapture: Transformation in the Victorian Dramatic Monologue. New York; Oxford: OUP, 2008.

Peterson, Linda H. "Sappho and the Making of Tennysonian Lyric." ELH 61 (1994): 121-37.

Prettejohn, Elizabeth. "Solomon, Swinburne, Sappho." Victorian Review 34 (2008): 10328. 
Prins, Yopie. "Elizabeth Barrett, Robert Browning and the Différance of Translation." Victorian Poetry 29 (1991): 435-51.

---. "Greek Maenads, Victorian Spinsters." Victorian Sexual Dissidence. Ed. Richard Dellamora. Chicago: U of Chicago P, 1999. 43-81.

---. "'Lady's Greek' (with the Accents): A Metrical Translation of Euripides by A. Mary F. Robinson." Victorian Literature and Culture 34 (2006): 591-618.

---. Victorian Sappho. Princeton: Princeton UP, 1999.

---. "'Violence Bridling Speech': Browning's Translation of Aeschylus's Agamemnon." Victorian Poetry 27 (1989): 151-70.

Pulham, Patricia. "From Pygmalion to Persephone: Love, Art and Myth in Thomas Hardy's the Well-Beloved." Victorian Review 34 (2008): 219-39.

Radford, Andrew D. The Lost Girls: Demeter-Persephone and the Literary Imagination, 1850-1930. Amsterdam: Rodopi, 2007.

Redpath, Theodore. "Tennyson and the Literature of Greece and Rome." Studies in Tennyson. Ed. Hallam Tennyson. Totowa, NJ: Barnes and Noble, 1981. 107-10.

Rendall, Vernon. "George Eliot and the Classics." A Century of George Eliot Criticism. Ed. Gordon S. Haight. London, 1966. 215-26.

Reynolds, Margaret, ed. The Sappho Companion. Basingstoke: Palgrave Macmillan, 2003.

Reynolds, Matthew. "Browning and Translationese." Essays in Criticism 53 (2003): 97128. 
Riley, Kathleen. The Reception and Performance of Euripides' Herakles: Reasoning

Madness. Oxford: OUP, 2008.

Rose, Jonathan. The Intellectual Life of the British Working Classes. London: Yale UP, 2001.

Sachs, Jonathan. "Greece or Rome?: The Uses of Antiquity in Late Eighteenth- and Early Nineteenth-Century British Literature." Literature Compass 6 (2009):

10.1111/j.1741-4113.2008.00612.x

Sacks, Peter M. The English Elegy: Studies in the Genre from Spenser to Yeats. Baltimore; London: Johns Hopkins UP, 1985.

Stray, Christopher, ed. Classics in 19th-and 20th-Century Cambridge: Curriculum, Culture and Community. Cambridge: Cambridge Philological Society, 1999.

---. Classics Transformed: Schools, Universities, and Society in England, 1830-1960.

Oxford: Clarendon, 1998.

---. Oxford Classics: Teaching and Learning, 1800-2000. London: Duckworth, 2007.

Sutphin, Christine. "The Representation of Women's Heterosexual Desire in Augusta

Webster's "Circe" And "Medea in Athens"." Women's Writing 5 (1998): 373-92.

Thain, Marion. "Michael Field": Poetry, Aestheticism and the Fin de Siècle. Cambridge:

CUP, 2007.

Thomson, J.A.K. The Classical Background of English Literature. London: G. Allen \& Unwin, 1948. 
Travis, Roger. "From "Shattered Mythologies" To "An Epic Life": Casaubon's Key to All Mythologies and Dorothea's Mythic Renewal in George Eliot's Middlemarch." International Journal of the Classical Tradition 5 (1998-9): 367-82.

Tucker, Herbert F. Epic: Britain's Heroic Muse, 1790-1910. Oxford: OUP, 2008.

Turner, Frank M. Contesting Cultural Authority: Essays in Victorian Intellectual Life. Cambridge: CUP, 1993.

---. The Greek Heritage in Victorian Britain. London: Yale UP, 1981.

---. "Why the Greeks and Not the Romans in Victorian Britain?" Rediscovering Hellenism: The Hellenic Inheritance and the English Imagination. Ed. G.W. Clarke. Cambridge: CUP, 1989. 61-81.

Turtle, Will. "'The Truth of Mere Transcript': Browning's Agamemnon." Translation and Literature 14 (2005): 196-211.

Vance, Norman. The Victorians and Ancient Rome. Oxford: Blackwell, 1997.

---. "Horace and the Nineteenth Century." Horace Made New: Horatian Influences on British Writing from the Renaissance to the Twentieth Century. Eds. Charles Martindale and David Hopkins. Cambridge: CUP, 1993. 199-216.

---. "Victorian." A Companion to the Classical Tradition. Ed. Craig Kallendorf. Oxford: Blackwell, 2007. 87-100.

Vasunia, Phiroze. "Greek, Latin, and the Indian Civil Service." The Cambridge Classical Journal: Proceedings of the Cambridge Philological Society 51 (2005): 35-71. 
Wallace, Jennifer. "Elizabeth Barrett Browning: Knowing Greek." Essays in Criticism 50 (2000): 329-53.

West, Stephanie. "Classical Notes on Gerard Manley Hopkins." International Journal of the Classical Tradition 13 (2006-7): 21-32.

Wiesenfarth, Joseph. "The Greeks, the Germans and George Eliot." Browning Institute Studies 10 (1982): 91-104.

Winterer, Caroline. The Culture of Classicism: Ancient Greece and Rome in American Intellectual Life, 1780-1910. London: Johns Hopkins UP, 2002.

---. The Mirror of Antiquity: American Women and the Classical Tradition, 1750-1900.

Ithaca, NY: Cornell UP, 2007.

Woolf, Virginia. A Woman's Essays. Ed. Rachel Bowlby. Harmondsworth: Penguin, 1992. 